\title{
BEAUTIFUL SCARS: JEWELS IN ENGLISH RENAISSANCE DRAMA
}

\author{
LISA HOPKINS \\ Sheffield Hallam University, UK
}

\begin{abstract}
In An Englis[h[ expositor[:] teaching the in[ter]pretation of the harde[st] words [vsed] in our language, John Bullokar notes that the word carbuncle 'hath two significations, namely a precious stone, and a dangerous sore'.(sig. D2r) Generally speaking Renaissance texts keep these two meanings separate: in ways which are inevitably conditioned by the nature of their subject matter, Renaissance authors tend to be interested in exploring either the idea of carbuncle as jewel or the idea of carbuncle as tumour without ever registering the possibility of the alternative meeting for the word. Nevertheless the ambiguity is there: a jewel, a thing of beauty intended for the adornment of the body, is also in some sense potentially a disfiguring mark, a scar on the body marking the site of a trauma. In A Cyborg Manifesto, Donna Haraway asks "Why should our bodies end at the skin?" (online); in this essay, I shall argue that as far as Renaissance jewels are concerned, bodies do not in fact end at the skin, for jewels mark not the end of the body but an edge, a hinge between body and mind as much as between body and dress, in ways which activate fears about permeability, boundary blurring and the monstrous. One of the rare instances of evoking both senses of carbuncle comes in The Comedy of Errors, where Dromio of Syracuse, having defined the kitchen-maid Nell as "spherical, like a globe", says that "America, the Indies" are located in her nose, because it is 'all o'er embellished with rubies, carbuncles, sapphires, declining their rich aspect to the hot breath of Spain' (III.ii.120, 140-3). To varying extent, the horror of the gross, the extreme and the unnatural which is implicit here can be seen as potentially lurking in all Renaissance descriptions of jewellery.
\end{abstract}

Keywords: Renaissance drama, Renaissance art, jewels, human body

The Renaissance was a period fascinated by jewels. In some ways, though, all jewellery inherently spoke of pain and loss as much as of beauty. in Andrew Marvell's To his Coy Mistress, the wooer muses on how if there were only enough time, 
Thou by the Indian Ganges' side

Shouldst rubies find; I by the tide

Of Humber would complain. (250-1)

India was famous as a site of jewels - in Henry VI, Part Three, King Henry muses that "My crown is in my heart, not on my head; / Not decked with diamonds and Indian stones" (III.i. 62-3) - but the idea of simply "finding" them is no more credible than the pastoral abundance envisioned elsewhere by Marvell in The Garden, and is just as clearly a fantasy as that poem's prelapsarian vision. In fact "the Golconda diamond mines in Hyderabad were opened up in the seventeenth century" (Evans 130), and Marvell would have been well aware that rubies must be mined, with considerable difficulty, rather than simply "found". Pierre de la Primaudaye comments on the labour involved in Renaissance mining, observing that:

AS God declareth a great and maruellous prouidence in all his creatures (as we haue discoursed intreating vpon them) so also doth he manifest it vnto vs in the creation of mettals, and especially of gold and siluer, which are esteemed for the most precious. For we see how he hath hidden them in the most deepe places of the earth, and hath couered them with great and high mountaines: so that to dig $\&$ draw them out of their profound caues, men must therein so trauell, as if they had enterprised to ouerturne and to transport these lofty hils from one place to another, and to search and pierce through the earth from one side to another. (854-5)

There is also a faint sense in De la Primaudaye that it is not only the miners who are being incommoded and pained. We would look in vain for any protoecological sensibility in Renaissance attitudes to mining (or for any ethical concerns such as those about blood diamonds), but there was an idea of stones as living entities of sorts, for De la Primaudaye speaks of stones as being conditioned by humours in much the same way as Renaissance medicine supposed the human body to be:

[S]ome precious stones which are white, haue beene generated by an humour hauing the colour of water, which maketh them more cleere and more transparent then others: and so the variety which is in the colours of all stones, bee they greene, blew, red, purple, yealow, or of many mingled colours, one must iudge the humours whereof they did proceede at first to haue beene such: and that other precious stones which are not transparent proceed from troubled, blacke and obscure humours. (848)

De la Primdaudaye's implicitly anthropomorphising image tropes the gems as constituted by much the same processes as were thought to operate in the human 
body, and leaves open the possibility that their extraction from the earth might make mines too potential sites of scarring and loss.

Similar ideas also accrued to pearls, although these come from water rather than land. B. J. Sokol remarks on the recent claim that "Not until Renaissance times was the theory advanced that pearls were merely an oyster's way of dealing with irritants." This claim is true, but not sufficiently historically nuanced: it elides the important facts that a new understanding of pearl formation was not once and for all "discoverered," nor rapidly disseminated, nor all at once accepted or acclaimed. Rather, this understanding emerged in a piecemeal fashion, was repeatedly rediscovered, and took over a century to become generally known. By 1610 its main revisionary idea was multiply available in print, but was not seen as a scientific "fact," dogma, or new paradigm.

Clearly, though, the idea that a pearl was a response to pain was becoming increasingly available, and observers like Sir Richard Hawkins were beginning to wonder whether older ideas were not "some old philosopher's conceit, for it can not be made probable how the dew should come into the oyster." (Cf. Kunz and Stevenson 38) Sokol also cites the wildly anthropomorphising perspective on pearl formation offered in Philemon Holland's 1601 translation of Pliny's Natural History (which G. F. Kunz argues that Shakespeare may have seen) (46):

This shell-fish which is the mother of Pearle, differeth not much in the manner of breeding and generation, from the oysters: for when the season of the yeere requireth that they should engender, they seeme to yawne and gape, and so doe open wide; and then (by report) they conceive a certaine moist dew as seede, wherewith they swell and grow bigge; and when time commeth, labour to be delivered hereof: and the fruit of these shellfishes are the pearles, better or worse, great or small, according to the qualitie and quantitie of the dew which they received. For if the dew were pure and cleare which went into them, then are the pearles white, faire, and orient: if grosse and troubled, the pearles likewise are dimme, foule, and duskish; pale (I say) they are, if the weather were close, darke, and threatening raine in the time of their conception. (Sokol 33)

Pearls, in this account, are conceived and brought forth almost like human babies, subject to the same process of an internal engendering precipitated by an external force, born of a "mother" after a "labour", and liable to display the characteristics of both "parents". Similar associations can be seen in Thomas Lodge's A Margarite of America, where a pearl is worn by the heroine in honour of her name, Margarite (which means pearl). Positioned provocatively close to her body - "O curious Gem how I enuie each while, / To see thee play vpon my 
Ladies paps" (sig.C2v) - it is implicitly associated with the language of conception and fructification:

And now thou plaist thee in that Garden gentill, Twixt golden fruite and neere her heart receiuest Thy rest, and all her secret thoughts conceiuest Vnder a vaile faire, white, diuine, and subtill.

Following the logic of Pliny, the whiteness of the pearl is read as reflecting the conditions of its conception in the shape of the purity of Margarite's own thoughts.

If jewels were like people, it was also common to figure people as jewels, as in Shakespeare and Fletcher's Henry VIII where Norfolk says of the king that Catherine "like a jewel has hung twenty years / About his neck, yet never lost her lustre" and the Lord Chamberlain says of Anne Boleyn that "from this lady may proceed a gem / To lighten all this isle." (II.ii.30-31, II.iii, 78-9) In Lodge's A Margarite of America the pearl worn by the heroine is in fact imagined as effectively interchangeable with the narrator:

Oh if I might from out your essence take you, And turne my selfe to shape what ere I would, How gladly would I be my Ladies Iewell?

Similarly in Tamburlaine the Great, Part One, we are told of the hero that

'twixt his manly pitch

A pearl more worth than all the world is placed,

Wherein by curious sovereignty of art

Are fixed his piercing instruments of sight. (II.i.11-14)

It is fitting that Tamburlaine, himself a freak of nature, should be associated with the monstrous birth of the pearl in this cyborg-like image of his head itself being made of pearl. Alternatively the gem can be an extension or emanation of the person, as in Richard III where Elizabeth's tears are figured as pearls:

The liquid drops of tears that you have shed

Shall come again, transformed to orient pearl,

Advantaging their love with interest. (IV.iv.321-3)

Here the association of jewels with loss and pain is particularly clear as the pearls become the reified tokens of the bereaved queen's grief.

The suggestion of a parallelism and a potential reciprocity between jewels and people was reinforced by the idea that jewels could act directly on 
bodies, effectively by a sort of sympathetic magic. This is an idea evocatively captured by Oscar Wilde in The Picture of Dorian Gray, when we read how Dorian's aesthetic sensibilities led him to collect jewels:

He discovered wonderful stories, also, about jewels ... According to the great alchemist, Pierre de Boniface, the diamond rendered a man invisible, and the agate of India made him eloquent. The cornelian appeased anger, and the hyacinth provoked sleep, and the amethyst drove away the fumes of wine. The garnet cast out demons, and the hydropicus deprived the moon of her colour. The selenite waxed and waned with the moon, and the meloceus, that devours thieves, could be affected only by the blood of kids. (156-7)

Wilde lifted this pretty much wholesale from William Jones' History and Mystery of Precious Stones, which gives a doubtful reference in Nostradamus as the source of the supposed comments by Boniface (14), but similar ideas can be readily found elsewhere, sometimes with the proviso that "Contact with the wearer was essential; occasionally open backs on pendants and rings allowed the stone to touch the skin" (Robinson 114). Albertus Magnus advised his readers, "If thou wilt prouoke sorowe, feare, terrible fantasyes, \& debate. Take the stone, which is called Onyx, which is of black coloure" (sig.C1v). Some stones could in effect do magic; not for nothing does Cornelius in Doctor Faustus claim that

He that is grounded in astrology,

Enriched with tongues, well seen [in] minerals,

Hath all the principles magic doth require. (I.i.140-2)

Magnus suggested that "If thou wilt knowe whyther thy wyfe is chaste, or no. Take the stone, which is called Magnes in English, the lode stone, it is of sadde $\mathrm{bl}[\mathrm{e}] \mathrm{w}$ coloure, and it is fou de in the sea of Inde sometime in partes of Almaine ... Laye thys stone vnder the head of a wyfe \& yf she be chast, she wil embrace her husbande, if she be not chaste, she wil fall anone forth of the bedde" (sig. $\mathrm{C} 1 \mathrm{r}$ ). Since it is hard to see what natural explanation could account for this, we are forced to fall back on a supernatural one.

Other stones could be used for what we might now be tempted to class as effectively medicinal purposes. Magnus informed his readers that "If thou wilt haue good vnder standing of thynges that may be felte, and that thou maye not be made dronked. Take the stone, whi[c] he is called Amaristus, and it is of purple colour, and the beste is found in Inde, and it is good agaynst dru $\sim$ kennes, and geueth good vnderstandynge in thynges that maye be vnderstande" (sig. C6r), the underlying logic here being the etymology of the word amethyst, which derives from the Greek amethustos, meaning "not drunk". De la Primaudaye, however, qualifies the advice by observing that amethysts prevent drunkenness only if tied to the navel; he also declares that a diamond "being tied 
to the flesh of the left arme ... doth hinder and withstand the feares of night", while rubies make one joyous and drinking sapphires cures melancholy (848-50) (though James Robinson also notes that "Sapphires were prized for their celestial connotations but also because they cooled the body and chastened the spirit. They are known to have been chosen for bishops' rings for that reason") (113). De la Primaudaye also declares that emeralds, if drunk, render poison inoperative, and Vitelli in Massinger's The Renegado, who is disguised as a merchant for much of the play, ascribes similar protective powers to a gold and diamond dish:

True to the owners,

Corinthian plate studded with diamonds

Concealed oft deadly poison; this pure metal

So innocent is and faithful to the mistress

Or master that possesses it that, rather

Than hold one drop that's venomous, of itself

It flies in pieces and deludes the traitor. (I.iii.121-7)

Heather L. Sale Holian notes that such ideas were particularly attractive to rulers, who might reasonably be considered at greater risk of being poisoned, and points specifically to "King Philip II and Queen Elizabeth, who wore and were given jewelry, respectively, set with stones believed to have protective powers." $(148-173,149, \mathrm{n} 2)$

In some cases there was imagined to be an effectively reciprocal relationship between people and stones. A surprising number of gems were sometimes said to originate inside animal or maybe even human bodies: according to Stephen Bateman's 1582 translation of Bartholomaeus Anglicus, which lists a number of stones rarely or never heard of elsewhere and allocates each one its own chapter, asterites "is found in the mawe of a pure maid, that is fifty yeres of age, or else among the Troglodites," noset "is taken out of a Toads head," and reyben "is found in a Crabs head," and the final chapter refers briefly to "the stone that groweth in ye Snaile, and ... the stone that growes in the maw of an Oxe." (Book 16, Chs. 18, 71, 86, 194) At least some of these are credited with properites directly related to their supposed places of origin: allectoria, for instance, is a stone that is found "in the mawes of capons," that is, castrated roosters, and its properties are similarly focused on testicles in that "the stone exciteth ye seruice of Venus" (chapter 18), while bitumen, which is described as "gendering" in the soft earth of marshy ground, has properties that reflect this sense of being born of mother Earth: it "is not broke with water nor with yron, but onelye with menstruall bloud ... it is good to helpe the passions of the mother" (chapter 20). Other stones too were operative on specific genders: crystal "filleth breasts and teates full of milke, if ye milke faileth before because of colde" (chapter 31); geraticen "is a blacke stone ... if a man wash cleane his 
owne mouth, \& beareth the stone therein: he may anone tel what other men thinke of him" (chapter 52); and iena or ienia "is a precious stone that is founde in the eyen of a beast that is called Hiena, $\&$ if this stone be put vnder a mans tongue, they say, that he shall tell many things that shall befall" (chapter 56).

Not only jewels themselves but also the designs of their settings were seen as meaningful and symbolic, and they too were seen as being able to signify and recall damage and loss, this time of a specifically cultural nature. Joan Evans in A History of Jewellery 1100-1870 starts her account of the Renaissance period by observing that: "The jewellery of the Renaissance was, like every kind of contemporary art, affected by that of classical antiquity', but she also notes that "Classical jewellery was little known and never imitated; only engraved gems formed any real link between the Roman past and the Renaissance present". (81) A sense of loss and of the irrecoverability of the classical past is thus inscribed at the heart of Renaissance narratives of jewels. Nor was this a phenomenon confined to explicitly classicising jewellery. Biblical-themed jewels were particularly popular - Evans notes that

The portraits of Catherine Howard painted about 1521 show her wearing an oval gold pendant set with a sapphire, chased with the story of Tobit, and Princess Mary Tudor's inventory of 1542 lists brooches with the stories of the finding of Moses, Moses striking the rock, Susanna, Solomon, Abraham, David, Noah and Jacob's Dream, as well as subjects drawn from the New Testament. The only recognisably secular subjects in her pictorial jewels, indeed, are a brooch with the history of Pyramus and Thisbe and another with "an Antike" and a French motto. (94)

There was a particular vogue for IHS - "Jesus" - pendants, of which Anne of Denmark had one.(Evans 97) All these, though, could also be read as reminders of man's fallen state and of human incompleteness in the absence of God, not to mention their potential for evoking the fraught landscape of religious schism. Martina Bagnoli notes that in the mediaeval period "Christian lapidaries usually concentrated on the stones mentioned in the Bible, which were often compared to virtues", (138) but other meanings could also be invoked, potentially in ways which pointed up the different interpretative preferences of the two confessions. This can be seen in the case of amethyst, whose reputation as a preventer of drunkenness could be subject to suggestive inflection: classical legend had it that a nymph named amethyst was turned to quartz by Diana to save her from Dionysos, who then in his remorse shed tears on the stone, which was turned purple because of his vinous nature. Dionysos was a figure often perceived as the antithesis of Christ, and this in conjunction with the twin associations of transformation and wine could give amethysts Eucharistic connotations. (Robinson 114) Something of this may be evoked in Ford's The Broken Heart, where the mad Penthea's seemingly nonsensical lament that "every drop / Of 
blood is turnèd to an amethyst, / Which married bachelors hang in their ears" (IV.ii.129-31) may perhaps encode a religious sensibility. I have argued elsewhere that the pervasive starvation and blood imagery of the play may trope a spiritual inanition and a nostalgia for the real presence of the body and blood in the Mass as opposed to the sublimated metaphors of Protestantism.(Hopkins ch. 3) As Penthea dies pining for the husband she cannot have and the food she will not eat and which does not nourish, the amethyst becomes the charged and emotive emblem of her loss and lack.

Other jewellery of the period would seem, to modern eyes at least, to have more simply ironic overtones - heart pendants were thought to signify constancy, and the six-times-married Henry VIII had thirty-nine of them (Evans 98)- while others spoke unequivocally of death: "Queen Elizabeth wore a book containing a copy of the last prayer of Edward VI, in golden covers," and a particularly famous piece of the period was the Lennox jewel, commissioned in memory of Margaret Lennox's murdered husband. Joan Evans observes more generally that "In the second half of the sixteenth century ... a constant preoccupation with death became once more a fashionable devotional trend, and appears in jewellery designs." $(101,116,142)$ Change and loss of a different sort are encoded at both ends of the story of the jewel known as the Mirror of Great Britain, which Roy Strong observes was "clearly designed to be a most important Crown jewel commemorating the historic union of the kingdoms in 1604." (351) To make it, the historic Scots crown jewel known as the "Great Harry' was broken up and one of its stones symbolically reused in this new British context, but the new jewel had to be pawned in 1625 and ultimately passed to the ownership of the French crown. The jewel thus spoke both of the loss of Scotland as a state securely separate from England and of the parlous finances of the new "British" crown.

Jewels could also be used effectively as branding, in ways which not only spoke of wealth and privilege but also pointed up the constraints which family and class imposed on individual women's identities. Heather Sale Holian has clearly shown this process at work in portraits of female members of the Medici family. She observes that: "In portraits of their female family members, the Medici used jewellery to demonstrate family ties and new alliances, and, by implication, political obligations and expectations, dynastic strength and stability, and ultimately power," and notes particularly "The established association of the diamond with the Medici dynasty ... The Medici adopted the single point-cut diamond, set within a gold ring, as a familial device already in the early fifteenth century;" thus "diamond and ruby were frequently worn by Medici women of these years, at times with pearls, but most often to the exclusion of any other gemstone when familial claims were being conveyed." $(149,152)$ Many of these women came to bad ends in ways often commemorated in Renaissance drama. One of these plays was Webster's The White Devil, which had Isabella de' Medici as a central character, and The 
Duchess of Malfi too focused on an Italian duchess, albeit not a Medici one. Samuel Schuman notes that in both these plays "The jewel and the ring are both ambiguous objects, embodying an ambiguity which is thematically germane to Webster's tragedies": "Each time rings and jewels appear in the first two acts of The White Devil the institution of marriage is mocked." He also observes that "A 'jewel' may be that which is most precious to a woman - her honor, more specifically her chastity ... In a related sense, 'jewel' or 'jewels' have been used to describe both the male and female genitals." $(253,60,254)$ Schuman is certainly right that the metaphor can apply to both men and women, as in The Renegado where Carazie describes being made a eunuch as "but parting with / A precious stone or two" (III.iv.52-3), but it is much more commonly used of women, as in All's Well That Ends Well where Diana says "Mine honour's such a ring; / My chastity's the jewel of our house." (IV.ii, 45-6) This both reifies female chastity and makes it something which is to be owned, a possession of a particularly valuable and sought-after kind which confers status on the male owner rather than on the woman herself. Valerie Traub observes that "the equation of female body parts with precious gems - the body metaphorically revealed, undressed and dismembered through the poet-lover's voyeuristic gaze - is a crucial strategy in the attempt both to construct a modern masculine subjectivity and to exert control over a situation in which the poet-lover's power is limited and secondary."(131)

David Golz suggests that this was particularly true of diamonds:

Diamonds were hardly common material objects in late medieval and early modern England, yet in language and literature they gathered about them an array of cultural implications. Everyday speakers linked them, of course, with wealth and treasure, but also with innocence and virginity, and the writers of romances used them to symbolize the idealized, unalloyed beauty of the chaste females who were the objects of their heroes' quests. Players on the London stage in the time of Shakespeare invoked them to mark the role of the eminently desirable woman.(168)

In The Duchess of Malfi the equation of women and diamonds is made explicit in the exchange between the Duchess and her brother: "Diamonds are of most value / They say, that have pass'd through most jewellers' hands", to which he counters "Whores, by that rule, are precious" (Webster I.i.299-301). A jewel, albeit this time a less specific one, also figures the self when the Duchess says to Antonio,

One of your eyes is blood-shot - use my ring to't,

They say 'tis very sovereign - 'twas my wedding ring,

And I did vow never to part with it,

But to my second husband. (Webster I.i.404-7) 
In offering this ring to Antonio she is in fact, as he immediately perceives, offering him herself as a wife. Given the prominence of this language in the plays about them and of jewellery in their portraiture, it seems reasonable to suppose that these stage duchesses wore things which at least appeared to be jewels, even if they were not actually so. They would certainly have had to wear at least the rings to which they so often refer, and in that respect, and possibly in others, there would have been a visual as well as linguistic correlation between the jewels which marked these women's heritage and status and the disasters which befall them, with rings, so often specifically ones which identify them as being 'owned' by men, particularly implicated. The suggestion that the jewels might be equated with their sexuality would serve to reinforce the sense that, for them at least, jewels are the scars which show the site of the femininity which is their destruction.

Another playwright very much interested in jewels was Marlowe, but in him they work rather differently from in Webster. In The Jew of Malta, Barabas likes all jewels; at the start of the play, he praises

Bags of fiery opals, sapphires, amethysts, Jacinths, hard topaz, grass-green emeralds, Beauteous rubies, sparkling diamonds, And seld-seen costly stones of so great price. (Marlowe I.i.25-8)

Although he briefly registers the aesthetic appeal of shiny stones, it is clear that what he most values in jewels is their status as highly portable sources of wealth: they enclose "Infinite riches in a little room." (I.i.37) This, however, is a phrase fraught with irony on multiple levels. Intradiegetically, the audience registers that Barabas is deaf to the biblical echo of the phrase, which troped the baby Jesus in the womb of Mary. Extradiegetically, the image subsequently became associated with Marlowe's own death after its use by Touchstone in As You Like It, "it strikes a man more dead than a great reckoning in a little room," (Shakespeare III.iii.9-12) with the little room here evoking the room in Eleanor Bull's house where he was stabbed and died. In both these respects, Barabas' words evoke lac - from the characteristic perspective of an early modern audience, lack of the salvific Christianity from which his adherence to Judaism excludes him, and from our own, loss in the shape of the death that was so soon to befall the play's author.

This is typical of the way jewels work in Marlowe. On the surface, they are signs and repositories of wealth, thus Barabas assures Abigail that she need have no fear about their finances because he has a hidden fortune in jewels, consisting of "great pearls, / Rich costly jewels, and stones infinite." (I.ii.248-9) Just one of the pearls, his messenger later tells Selim-Calymath, is 
so big,

So precious, and withal so orient,

As be it valuèd but indifferently,

The price thereof will serve to entertain

Selim and all his soldiers for a month (V.iii.27-30)

Tamburlaine too likes pearls, musing on how fine it would be

To wear a crown enchased with pearl and gold,

Whose virtues carry with it life and death (II.v.60-1)

Here he evokes both the quasi-magical properties which jewels might have but also, more simply and more obviously, the money and hence the power they emblematise. Only occasionally are jewels in Marlowe valued for their intrinsic beauty or potential for adornment, as when Tamburlaine promises Zenocrate that "Thy garments shall be made of Median silk, / Enchased with precious jewels." (I.ii.95-6) Even more rarely do Marlowe's characters seem to invest jewels with sentimental value, and when they do it invariably presages disaster. Dido exhorts Aeneas,

Hold, take these jewels at thy lover's hand,

These golden bracelets, and this wedding-ring,

Wherewith my husband wooed me yet a maid,

And be thou King of Libya, my gift.(III.iv.60-3)

Dido, like the Duchess of Malfi, will learn all too soon that the woman who gives her first husband's wedding ring to a second is only too likely to come to grief, for it is no simple adornment but the scar which marks the site of her bereavement and what would to many in the early modern period appear as the wantonness of her subsequent decision to remarry.

Jewels in Marlowe's plays mark scars in other ways too. When Barabas figures his daughter Abigail as a diamond (III.i.57-8) it is if anything even more obvious than in the case of Dido that this is something which bodes ill for her since, as Alison Findlay shows, when women in Renaissance plays are referred to by men as jewels it is generally as part of a process of commodification which rarely ends well for them. (212-4) Above all, though, jewels in Marlowe's plays serve by their very changelessness to emphasise the change and decay to which humans are subject. In Tamburlaine the Great, Part One, Mycetes declares, "Well, well, Meander, thou art deeply read, / And having thee I have a jewel sure." (II.ii.54-5) Mycetes will soon die, and Meander will disappear from the play. Later, Tamburlaine himself apostrophises Zenocrate as one who

Rainest on the earth resolvèd pearl in showers

And sprinklest sapphires on thy shining face. (V.i.142-4) 
Early in Part Two, though, Zenocrate too will die and the golden coffin in which he will encase her remains will provide a bitter emblem of the permanence and durability which gems have but she does not. The jewel, then, is the scar which marks the wearer's vulnerability to death.

Shakespeare too is fond of using jewels in his plays, but he does so to rather different effect. Shylock may echo Barabas in associating his daughter with jewels, but the association works in different ways. As the news of Jessica's elopement breaks, Salerio says to Shylock, "There is more difference between thy flesh and blood and hers than between jet and ivory." (III.i.35-6) Hearing from Tubal the details of her flight and her extravagance, Shylock himself picks up this language when he wails "A diamond gone cost me two thousand ducats in Frankfurt! ... I would my daughter were dead at my foot, and the jewels in her ear!" (III.i.76-81) But there is worse still to come:

Tubal. One of them showed me a ring that he had of your daughter for a monkey.

Shylock. Out upon her! Thou torturest me, Tubal. It was my turquoise; I had it of Leah when I was a bachelor. I would not have given it for a wilderness of monkeys. (III.i.108-113)

Leah, we assume, was Shylock's wife and the mother of Jessica, and since we neither see nor hear of her anywhere else in the play, we assume that she is dead. The turquoise which is Shylock's souvenir of her was meant to protect the wearer from both mental care and physical harm: Pierre Boiastuau observes in Certaine secrete wonders of nature that "The Turquise (accordyng to the moste Philosophers) is of no singular propertie, but to chase awaye thoughtes and troubles of the braine," (41) while De la Primaudaye notes that "the Turkesse being worne in a ring doth keepe a man from hurt that falleth, yea though it be from his horse." (852) If a man did come to grief, though, any turquoise that he owns will grow pale in token of his sorrow, as Ben Jonson notes in Sejanus: "true as turquoise in the dear lord's ring, / Look well or ill with him." (I.i.37-8) It is, therefore, richly ironic that it should be this reputedly protective and sensitive stone that brings Shylock to the height of his distress, and that it should be for him the scar which marks what we are clearly invited to read as his own still-painful bereavement and loss, as well as the equally painful lack of Jessica's indifference to her family and heritage.

Other Shakespeare plays also feature stones (in the nineteenth century, T. F. Thiselton Dyer noted the importance of rings in particular), (online text) and again they characteristically deploy them with ironic force: G. F. Kunz's remark that "we find no trace in Shakespeare's works of any belief in the many quaint and curious supermanic or curative virtues of precious stones" I think misses the point, for Shakespeare's uses of stones work best if the audience is aware both of what they should achieve or be used for and the fact that in any 
individual instance they are spectacularly failing to produce that particular effect.(34) In The Tempest, Ariel sings,

Full fathom five thy father lies,

Of his bones are coral made;

Those are pearls that were his eyes,

Nothing of him that doth fade

But doth suffer a sea-change

Into something rich and strange.(I.ii.397-402)

De la Primaudaye, noting that although it is not strictly a jewel coral "is put into the number of stones", declares that "The properties which are attributed to Coral, are maruailous." (853-4) Specifically, Bateman's rendering of Bartholomeus Anglicus informed its readers that it "putteth off lightning, whirle winde, tempest and storned from Shippes," (Book 16, Ch.33) while Magnus declares that:

If thou wilt pacifie tempestes and go ouer fluddes. Take the stone, which is called Corallus, Corall ... it hath ben proueth that it stemmeth anone bloude, and putteth away the folishnes of hym that beareth it, \& geueth wysedom ... And it is good agaynst tempestes, and perils of fluddes. (sigs C6v-C7r)

It is, therefore, fraught with irony that this stone which is supposed to ward off tempests should be evoked by Ariel in direct connection with a disaster apparently caused by a tempest, while its other property of giving wisdom is similarly conspicuous by its absence in that Ferdinand during this scene has been comprehensively deceived: he is mourning for someone who is not dead on what he believes to be a deserted island on which he has been accidentally shipwrecked but which is in fact inhabited by someone who has planned what has happened to him. Similarly B. J. Sokol remarks of "those are pearls that were his eyes" that an implication arises that a vision-dimming or visiondestroying pearliness has overtaken Alonso's perceptual inlets: this aligns with the scientific meaning of "a pearl in the eye" for Shakespeare's age, which was a cataract (45).

There is certainly interest in eye diseases in another late play, The Winter's Tale, where Leontes is sure that Polixenes and Hermione wish "all eyes / Blind with the pin and web, but theirs," (I.ii.290-1) and there has indeed been some speculation that Shakespeare himself suffered from an eye disease towards the end of his life, ${ }^{1}$ so such a meaning may well be in play. Again, though, it is

\footnotetext{
${ }^{1}$ See for instance Rossella Lorenzi, "Shakespeare's eye betrays rare cancer". Online: http://www.abc.net.au/science/articles/2006/03/02/1582326.htm
} 
one which would be working to ironic effect, since blindness will soon give way to clear and accurate perception on the part of all the characters. To pair these two references allows a particularly sharp and focused apprehension of Shakespeare's characteristic technique in his uses of jewel imagery: coral, which should enable clarity of perception, is associated with a state of deception, while pearls, metaphorically associated with blindness, are here mentioned as part of the prelude to complete and clear revelation.

My final example from Shakespeare comes from Othello. Here the hero, who later castigates himself as one who "Like the base Indian, threw a pearl away / Richer than all his tribe," (V.ii. 345-6) declares that

Had she been true,

If heaven would make me such another world

Of one entire and perfect chrysolite,

I'd not have sold her for it. (V.ii.139-142)

As Valerie Traub points out, "the comparison of Desdemona to jewels is part of Othello's strategy for containing her erotic power. By imaginatively transforming Desdemona into a jewel - hard, cold, static, silent, yet also adored and desired - Othello is able to maintain both his distance from and his idealization of her'.(131) However, something else also seems to be at stake. Chrysolites are identified by De la Primaudaye as some of the most precious of jewels:

Now amongst precious stones, these beare away the prise, and are praised with especiall praise, the white diamond, for hardnesse, and soliditie: the greene emerauld for beawty, the red carbuncle, called the rubie, for liuely colour, the skie coloured saphir, for grace, the yealow chrysolite for splendor, the diuers coloured opall, for varietie, and the cleere pearle for whitnesse, and roundnesse. (848)

According to Bateman, "Crisolitus is a little stone of Ethiopia ... like to the sea in colour;" "it feareth feendes and ... comforteth the vnderstanding." (Book 16, Ch. 29) Magnus too is again pertinent here:

If thou wilt dryue away fantasies and folishnes. Take the stone, which is called Chrysolitus, and it is of the same vertue with Attemicus, as Aaro \& Euax say, in the boke of the nature of herbes, $\&$ stones: this stone set in golde, \& borne, dryueth away folishnes, \& expelleth fantasies. It is affirmed to geue wysedome, and it is good against feare. (sig. D2v)

Despite the affinity which their common origin in Africa might be supposed to give them, Othello has availed himself of none of the properties of the chrysolite: he has shown little wisdom, and has succumbed to the unjustified fear 
that Desdemona is betraying him. Irony is heaped on irony by the fact that the stone which supposedly "feareth" (i.e. frightens) fiends should be evoked by the only Shakespearean character who seriously imagines that a devil might actually and materially be in the room with him, as we see when he looks down at Iago's feet to see if they are cloven. All the way through the play, it has been apparent that Othello is too inclined to put his trust in narratives and stories, whether his own or those of others ${ }^{1}$; his glance at Iago's feet is a final instance of this, suggesting that he had been unable to conceive of an evil which was not clearly and simply manifested in easily readable terms. Othello's imagined chrysolite thus becomes the scar that marks both the precise qualities and the exact degree of epistemological sophistication which could have saved him from himself but which he has failed to show.

In John Ford's last play, The Lady's Trial, the heroine, Spinella, takes her name from a jewel, and Ford is very interested in general in the language of jewels. In The Fancies Chaste and Noble the marquis discusses knowledge of jewels with those around him:

\begin{tabular}{|c|c|}
\hline ROMANELLO & $\begin{array}{l}\text { I hope Sir } \\
\text { You cannot thinke I am a lapidarie - } \\
\text { I skill in Jewels? }\end{array}$ \\
\hline OCTAVIO & $\begin{array}{l}\text { 'Tis a proper quality } \\
\text { For any Gentleman; your other friends } \\
\text { May be are not so coy. }\end{array}$ \\
\hline JULIO & $\begin{array}{l}\text { Who, they? They know not } \\
\text { A Topaze from an Opall. }\end{array}$ \\
\hline CAMILLO & $\begin{array}{l}\text { We are ignorant } \\
\text { In gems which are not common. (5.3.45-51) }\end{array}$ \\
\hline
\end{tabular}

Julio and Camillo might, therefore, have been baffled by a spinel, from which Spinella derives her name, for it is an unusual gem, being usually red in colour (although blue is also not uncommon) but rather less precious than a ruby: a good woman may be above the price of rubies (Proverbs 31: 10), but a spinel is not quite a ruby, although Peter Martyr considers spinels equivalent in price to balas rubies, (424) and this is reflected in the play by the readiness with which Spinella, like Desdemona, is wrongly believed guilty of adultery. In Ford's early poem Fame's Memorial we are told that "Jewell's being had for Jewel's are not know'n;" (130) in his play The Broken Heart, Penthea figures her youth, her fame and her brother all as jewels (3.5.49-69); in Love's Sacrifice, the Duke boasts that

\footnotetext{
${ }^{1}$ For a fuller exploration of this, see Lisa Hopkins. "The representation of narrative: what happens in Othello". Journal X 1:2 (spring, 1997): 159-174.
} 
I am a monarch of felicity,

Proud in a pair of jewels rich and beautiful:

A perfect friend, a wife above compare. (I.i.131-2)

Here, jewels function first as an emblem of an innate inability to appreciate what we have, and secondly to trope things and people that Penthea and the Duke will very shortly lose for ever. Collectively, all these instances, together with the others I have cited, suggest that Julio and Claudio are quite wrong to scorn the knowledge of jewels, for a little learning in that field might well have saved the characters in many plays a great deal of trouble. Thus from Marlowe to Ford by way of Shakespeare and Webster, jewels in English Renaissance drama function not only as adornment, but also as beautiful scars, marking sites of loss and lack.

\section{Works Cited}

Anglicus, Bartholomaeus. Batman vppon Bartholome his booke De proprietaribus rerum. Trans. Stephen Bateman. London: Thomas East, 1582.

$\mathrm{B}[\mathrm{ullokar}, \mathrm{I}[\mathrm{ohn}]$. An Englis[h[ expositor[:] teaching the in[ter]pretation of the harde[st] words [vsed] in our languag. London: Printed by John Legatt, 1621.

Bagnoli, Martina. "The Stuff of Heaven: Materials and Craftsmanship in Medieval Reliquaries". Treasures of Heaven: Saints, Relics, and Devotion in Medieval Europe. Eds. Martina Bagnoli, Holger A. Klein, C. Griffith Mann and James Robinson. London: The British Museum Press, 2011. pp. 137-147.

Boiastuau, Pierre. Certaine secrete wonders of nature. London: Henry Bynneman, 1569.

De la Primaudaye, Pierre, The French academie Fully discoursed and finished in foure Bookes. London: Printed [by John Legat] for Thomas Adams, 1618..

Evans, Joan. A History of Jewellery 1100-1870. New York: Dover, 1970, [1953].

Findlay, Alison. Women in Shakespeare: A Dictionary. London: Continuum, 2010.

Ford, John. Fames Memoriall. The Nondramatic Works of John Ford. Eds. L. E, Stock, Gilles D. Monsarrat, Judith M. Kennedy and Dennis Danielson. Binghampton: Medieval and Renaissance Texts and Studies, 1991.

Ford, John. Love's Sacrifice. Ed. A. T. Moore. Manchester: Manchester University Press, 2002.

Ford, John. The Broken Heart. Ed. T. J. B. Spencer. Manchester: Manchester University Press, 1980).

Golz, David. "Diamonds, Maidens, Widow Dido, and Cock-a-diddle dow". Comparative Drama, 43.2 (summer 2008):167-196.

Haraway, Donna. "A Cyborg Manifesto: Science, Technology, and Socialist-Feminism in the Late Twentieth Century". (1985). Online: http://www.stanford.edu/dept/HPS/Haraway/CyborgManifesto.html

Hopkins, Lisa. "The representation of narrative: what happens in Othello". Journal X 1:2 (spring, 1997): 159-174. 
Hopkins, Lisa. John Ford's Political Theatre. Manchester: Manchester University Press, 1994.

Jones, William. History and Mystery of Precious Stone. London: Richard Bentley and son, 1880.

Jonson, Ben. Sejanus. Ed. Philip Ayres. Manchester: Manchester University Press, 1990.

Kunz, G. F. and C. H. Stevenson. The Book of the Pearl: its History, Art, Science and Industry. Mineola: Dover, 2001, [1908].

Kunz, G. F.. Shakespeare and Precious Stones. Philadelphia: J. B. Lippincott Company, 1916.

Lodge, Thomas. A Margarite of America. London: John Busbie, 1596.

Lorenzi, Rossella. 'Shakespeare's eye betrays rare cancer'. Online: http://www.abc.net.au/science/articles/2006/03/02/1582326.htm

Magnus, Albertus. The boke of secretes of Albertus Magnus of the vertues of herbes, stones, and certayne beasts. London: 1560.

Marlowe, Christopher. Dido, Queen of Carthage. Christopher Marlowe: The Complete Plays. Ed. Mark Thornton Burnett. London: Everyman, 1999..

Marlowe, Christopher. Tamburlaine the Great, Part One. Christopher Marlowe: The Complete Plays. Ed. Mark Thornton Burnett. London: Everyman, 1999.

Marlowe, Christopher. The Jew of Malta. Christopher Marlowe: The Complete Plays. Ed. Mark Thornton Burnett. London: J.M. Dent, 1999.

Marlowe. Christopher. Doctor Faustus, A text. The Complete Plays. Ed. Mark Thornton Burnett. London: J. M. Dent, 1999.

Martyr, Peter. The history of trauayle in the West and Easy Indies, and other countreys lying eyther way, towardes the fruitfull and ryche Moluccaes. Trans. Richard Eden. London, 1577.

Marvell, Andrew, "The Garden”. The Metaphysical Poets. Ed. Helen Gardner. Harmondsworth: Penguin, 1957.

Massinger, Philip. The Renegado. Ed. Michael Neill. London: Methuen, 2010.

Robinson, James. "From Altar to Amulet: Relics, Portability, and Devotion". Treasures of Heaven: Saints, Relics, and Devotion in Medieval Europe. Eds. Martina Bagnoli, Holger A. Klein, C. Griffith Mann and James Robinson. London: The British Museum Press, 2011.

Sale Holian, Heather L. "Family Jewels: The Gendered Marking of Medici Women in Court Portraits of the Late Renaissance".Mediterranean Studies (2008), pp. 148-173.

Schuman, Samuel. "The Ring and the Jewel in Webster's Tragedies". Texas Studies in Language and Literature 14 (1972): 253-268.

Shakespeare, William. All's Well That Ends Well. Ed. G. K. Hunter. London: Cengage Learning, 2007.

Shakespeare, William. As You Like It. Ed. Agnes Latham. London: Methuen, 1975.

Shakespeare, William. Henry VI, Part Three. Ed. Michael Hattaway. Cambridge: Cambridge University Press, 1993.

Shakespeare, William. Henry VIII. Ed. A. R. Humphreys. Harmondsworth: Penguin, 1971.

Shakespeare, William. Othello. Ed. E. A. J. Honigmann. London: Thomas Nelson and Sons, 1997. 5.2.139-142 and 5.2.345-6. 
Shakespeare, William. Richard III. Ed. E. A. J. Honigmann. Harmondsworth: Penguin, 1968.

Shakespeare, William. The Comedy of Errors. Ed. Stanley Wells. Harmondsworth: Penguin, 1972.

Shakespeare, William. The Merchant of Venice. Ed. M. Moelwyn Merchant. Harmondsworth: Penguin, 1967.

Shakespeare, William. The Tempest. Eds.Virginia Mason Vaughan and Alden T. Vaughan. London: Thomas Nelson and Sons, 1999.

Shakespeare, William. The Winter's Tale. Ed. J. H. Pafford. London: Methuen, 1963.

Sokol, B. J.. A Brave New World of Knowledge: Shakespeare's The Tempest and Early Modern Epistemology. London: Associated University Presses, 2003.

Strong, Roy. "Three Royal Jewels: The Three Brothers, the Mirror of Great Britain and the Feather". The Burlington Magazine ,vol. 108, no. 760 (July, 1996): 350333.

Thiselton Dyer, T. F.. Folk-lore of Shakespear.1883. Online: http://www.sacredtexts.com/sks/flos/flos 17.htm

Traub, Valerie. "Jewels, Statues, and Corpses: Containment of Female Erotic Power in Shakespeare's Plays". Shakespeare and Gender: A History. Eds. Deborah E. Barker and Ivo Kamps. London: Verso, 1995. pp. 120-141.

Webster, John. The Duchess of Malfi. Ed. John Russell Brown. Manchester: Manchester University Press, 1974.

Wilde, Oscar. The Picture of Dorian Gray. Harmondsworth: Penguin, 1984. 